Shkendije Geci Sherifi:

\title{
THE ROLE OF INTERNATIONAL ORGANISATIONS IN THE DEVELOPMENT OF SECURITY SECTOR IN KOSOVO: ADVANTAGES AND CONSTRAINS
}

\section{DOI: $10.35926 /$ HDR. 2019.1-2.7}

\begin{abstract}
Pursuant to UNSC Resolution 1244, following the war and the NATO bombing campaign, Kosovo was placed under an international administration, by the United Nations Interim Administration Mission in Kosovo (UNMIK). After the end of the war, the course of the security policies in Kosovo was directed mainly by international actors. Basically, the security sector was non-existent, whereas the international military and civilian presence was responsible for the security of Kosovo's borders and the protection of public order. The responsibility for security thus belonged to the international community and was progressively transferred to the Kosovo security institutions. While in the beginning, the takeover of security by the international community was a necessity in order to provide peace and stability, the prolongation of the delegation of ownership to local institutions created disadvantages in terms of timely and professional development. During international administration, the undefined political status of Kosovo influenced the security sector as an area reserved for the international community.
\end{abstract}

KEYWORDS: International Organisations, security, policy, peace, stability

\section{INTRODUCTION}

Given that in 2001 the final status of Kosovo was not resolved yet, based on United Nations Security Council (UNSC) Resolution 1244 (1999) of June 10, 1999, Regulation 2001/9 on establishing a Constitutional Framework for Provisional Self-Government in Kosovo was promulgated for the purposes of developing an essential but provisional self-government. Through this constitutional framework, UNMIK delegated significant responsibilities to the local institutions in "the legislative, executive and judicial field through the participation of the people of Kosovo in free and fair elections." However, some very important areas, including the security sector, continued to be the direct authority of the international presence in Kosovo, namely UNMIK.

The inclusion of Kosovo institutions in the security sector started after the commencement of the security sector review process.

\footnotetext{
1 "UNMIK/REG/2001/9. On a Constitution Framework for Provisional Self-government in Kosovo". 15 May 2001. http://www.unmikonline.org/regulations/2001/reg09-01.htm, Accessed on 16 July 2019.
} 
The Kosovar Centre for Security Studies defines three key periods of Security Sector Reform (SSR) along with overall political developments. ${ }^{2}$ The first period entails the years 1999-2005 and it signifies the Security Sector Building (SSB) phase which includes the efforts made towards building security institutions such as the Kosovo Police Service (KPS), Kosovo Protection Corps (KPC) and other relevant bodies. ${ }^{3}$ This is the period where security related responsibilities were reserved for the Special Representative of the Secretary General whilst only limited responsibilities were vested to locals. The second period, covering the end of 2005 till the beginning of 2008, notes the beginning of the handover of responsibility from the international community to the locals. ${ }^{4}$ In this period, the major significance lies with the Internal Security Sector Review (ISSR) as it notes not only the creation of the new security architecture, like the establishment of two rather relevant ministries, the Ministry of Internal Affairs and the Ministry of Justice in Kosovo, but it also assesses the state of play of the security sector of that time. The third period is related to the declaration of Independence as well as the entry into force of the Constitution of the Republic of Kosovo indicating that the new security architecture in Kosovo permits the creation of new security institutions such as the Kosovo Security Force (KSF), Kosovo Security Council (KSC), Kosovo Intelligence Agency (KIA), including police reform, and establishment of emergency services. Furthermore, the SSR referred to the gradual transformation of the KSF into the Kosovo Armed Forces (KAF) whose mission will be the protection of the territorial sovereignty and integrity of Kosovo, whereas the MKSF will be turned into the Ministry of Defence (MoD) that will exercise civilian and democratic control of the KAF. ${ }^{5}$

The role of international organizations in the creation and structuring of the security mechanisms has been indispensable while the local ownership was evidently deficient. The shaping and direction of the security policies in Kosovo after the end of the war was conducted mainly by the international actors as responsibility for security belonged to the international community and was progressively transferred to the Kosovo security institutions. While the takeover of security from the international community was a necessity in order to provide peace and stability, the prolongation of the transfer of ownership to the local institutions created disadvantages in terms of timely professional development.

According to the US State Department, Diplomacy in Action - International Support for Kosovo, the US is committed to work with the Government of Kosovo and the European and international partners for the continued progress and development of Kosovo for the benefit of its citizens while amongst others, identifying the following organizations: United Nations Interim Administration Mission in Kosovo (UNMIK), International Civilian Office (ICO), OSCE Mission in Kosovo (OMIK), NATO's Kosovo Force (KFOR). ${ }^{6}$ Each of these organizations has a particular role and will be analysed mainly from security perspective and the impact they had in building the security architecture, legislation and policy.

\footnotetext{
2 "Chronology of Security Sector Reform in Kosovo". Kosovar Center for Security Studies (KCSS). Pristina, 2009. http://www.qkss.org/repository/docs/Chronology_of_Security_Sector_Reform_in_Kosovo_609982.pdf

3 "Chronology of Security Sector Reform in Kosovo".

4 "Chronology of Security Sector Reform in Kosovo".

5 "Chronology of Security Sector Reform in Kosovo".

6 "International Support for Kosovo". U.S. State Department of State. https://2009-2017.state.gov/p/eur/ci/kv/ c27789.htm, Accessed on 12 July 2019.
} 


\section{UNITED NATIONS MISSION IN KOSOVO}

Following NATO's military campaign in 1999, the UNSC adopted Resolution 1244, authorizing UNMIK to start an extensive process of building peace, democracy, stability and self-government in Kosovo. ${ }^{7}$

It is important to emphasize that Resolution 1244 presents one of the most disputable and paradoxical resolutions of the UN for many scholars. I consider that one of the strongest arguments to put forward is that since the FRY ceased to exist, this makes Resolution 1244 extraneous and consequently it makes Kosovo independent by default.

In accordance with Resolution 1244, the Constitutional Framework and the original standards statement, approved by the Security Council, a policy document under the name "Standards for Kosovo" was developed. This document set out a number of standards that Kosovo had to accomplish. As Bernard Knoll indicates, "These standards reinforce Kosovo's parallel progress towards European standards in the framework of the EU's Stabilisation and Association Process, based inter alia on the Copenhagen criteria. The standards describe a multi-ethnic society where there is democracy, tolerance, freedom of movement and equal access to justice for all people in Kosovo, regardless of their ethnic background". 8

Since summer 2002, UNMIK has submitted regular baseline reports on standards implementation to the UNSC. Knoll describes that "since early 2003, the benchmarking process has been reinforced by the Tracking Mechanism for Kosovo, through which the European Commission tracks the development of standards and provides sector-specific recommendations for different policy areas. Under the Tracking Mechanism, Kosovo is obliged to gradually bring its legislation and institutions into line with the EU acquis, and receives access to the EU market in return." Despite the fact that these mechanisms were set long time ago, still, to this day, Kosovo lags way behind the countries of the region in terms of EU integration process.

The unrest of March 2004 certainly presented a drawback in the process. Furthermore, it damaged the reputation and the credibility of UNMIK and KFOR. The inter-ethnic violence of March 2004 was a clear indicator that proved that the international community's efforts to create a harmonious multi-ethnic society in Kosovo had failed, or as the report on the international commission in the Balkans puts it: "A multi-ethnic Kosovo does not exist except in the bureaucratic assessments of the international community. The events of March 2004 amounted to the strongest signal yet that the situation could explode." ${ }^{10}$ Certainly, this situation made the UN rethink its approach and take steps towards the change of the status quo.

Consequently, on 23 May 2005, Secretary General Kofi Annan appointed Mr. Kai Eide of Norway as a Special Envoy to undertake a comprehensive review of the situation in Kosovo in order to assess if the conditions are ready to start the political process that would determine the future status of Kosovo. He concluded that although the standards implemen-

\footnotetext{
${ }^{7}$ You may access the resolution in the official UN language in the following link: "Security Council Resolution 1244 (1999) on the situation relating Kosovo". United Nations Peacemaker. https://peacemaker.un.org/kosovo-resolution1244, Accessed on 16 February 2019.

8 Knoll, B. "From Benchmarking to Final Status? Kosovo and The Problem of an International Administration's Open-Ended Mandate”. European Journal of International Law 16/4. September 2005. 4-12. DOI: $10.1093 /$ ejil/chi140

${ }^{9}$ Knoll. "From Benchmarking to Final Status?..."

${ }^{10}$ International Commission on the Balkans. The Balkans in Europe's Future. Sofia: Secretariat Centre for Liberal Strategies, 2005. 19.
} 
tation in Kosovo had been uneven, the status quo was unsustainable and the time had come to move to the next phase of the political process and launch negotiations on the future status of Kosovo. ${ }^{11}$

On 1 November 2005, Kofi Annan appointed former Finnish President Martti Ahtisaari as a Special Envoy to lead the political process that would resolve the future status of Kosovo. Martti Ahtisaari's appointment signalled the commencement of the last part of the international administration of Kosovo in its present form, furthermore it signalled that the time for the European Union's intense involvement in this issue had come. ${ }^{12}$

On February $2^{\text {nd }}, 2007$ UN Secretary-General's Special Envoy Martti Ahtisaari presented the plan for the future status process of Kosovo. According to this proposal, the minority communities will be granted special protection while the municipalities will undergo a process of decentralisation in order to ensure that the rights and interests of non-Albanian communities are protected. In this light, Kosovo would govern itself under international supervision but would have the right to enter into international agreements, including membership of international bodies. The Secretary-General, Ban Ki-moon considered the proposal as fair and balanced. Additionally, the proposal entailed the deployment of an international civil and military presence that would supervise the new arrangements and ensure peace and stability. A European Union (EU) Special Representative would act as an International Civilian Representative, with ultimate supervisory authority over the civil aspects of the settlement, including the power to annul laws and remove officials whose actions are determined to be inconsistent with it. ${ }^{13}$

On April 3, 2007 Ahtisaari presented to the UNSC his final package of proposal recommending that Kosovo should become an independent state with a period of international supervision. Kosovo accepted the proposal while Serbia rejected it. Throughout April-July, 2007, a number of draft resolutions based on Ahtisaari's plan were rejected by Russia in the UNSC. Consequently, Ban Ki-Moon authorized a time-limited round of negotiations between Pristina and Belgrade led by an EU/US/Russian Troika. The unsuccessful diplomatic efforts of the Troika to bridge the gap between the parties on Kosovo's status eventually led to the unilateral declaration of independence but in coordination with the major powers.

In addition to having a paradoxical and disputed mandate, UNMIK also had policies which have been widely and deeply criticized as having had detrimental effects on Kosovo and its society. It is arguable that the status quo that was maintained by this organization did not allow the proper maturation of Kosovo institutions and was not working to achieve its goals within the society, but rather had built a hostile tension that culminated with the 2004 unrest, proving the administration was far from what it proclaimed and was not succeeding at all in its mandate. Another policy is that of the decentralization, which was supposed to increase the security of the non-majority communities in Kosovo but arguably yielded a very different result. Decentralisation turned many cities in Kosovo into ethnically homogenous

11 Annan, K. A. "Letter dated 7 October 2005 from the Secretary-General addressed to the President of the Security Council". 7 October 2005. https://www.securitycouncilreport.org/atf/cf/\%7B65BFCF9B-6D27-4E9C-8CD3CF6E4FF96FF9\%7D/Kos\%20S2005\%20635.pdf, Accessed on 12 July 2019.

12 "Secretary-General Appoints Former President Martti Ahtisaari of Finland as Special Envoy for Future Process for Kosovo". United Nations. https://www.un.org/press/en/2005/sga955.doc.htm, Accessed on 16 February 2019.

13 "Comprehensive Proposal for the Kosovo Status Settlement”. United Nations Office of the Special Envoy for Kosovo (UNOSEK). 2 February 2007. http://www.kuvendikosoves.org/common/docs/Comprehensive\%20Proposal\%20.pdf 
spaces, where previously there had been multi-ethnicity, in turn creating enclaves where the Serbs constituted a majority. Such a constitution brought about a total ethnic separation between the Albanians and the Serbs, who now could very easily avoid frequenting the areas where the other ethnic group was a majority. While how such a process contributed to the physical security of the Serb population in the decentralized enclaves is vague and inconclusive to say the least, it did a great deal to contribute to an array of other insecurities, with economic insecurity being at the very top. For a country where employment opportunities are weak for many groups even in the largest cities, to find such opportunities in enclaves or villages is imaginably even more unlikely. In addition to economic insecurity, decentralization made cultural exchange between the Albanian majority and Serbian minorities extremely difficult. Instead of natural encounters between the two populations who previously lived in the same cities, this exchange now had to be "facilitated" by international actors through workshops and other artificially stimulated conditions. Moreover, this very process helped create an atmosphere of insecurity in the country, by sending the message that the minorities had to be protected from some sort of threat, which was also unfair to the majority. With a lack of such encounters and exchange extreme narratives about the other risk to grow, increasing hostilities between the communities, and ultimately contributing to overall insecurity.

\section{INTERNATIONAL CIVILIAN OFFICE}

The International Civilian Office (ICO) had a significant impact on building important segments of the security architecture in Kosovo. ICO was in charge of the supervision of the implementation of the Comprehensive Settlement Proposal, widely known as the Ahtisaari Plan, by the Government of Kosovo. The ICO was led by the International Civilian Representative (ICR), Pieter Feith, appointed by the ISG. The ICO finished its work in Kosovo in September 2012 and presented a rather unique international body because unlike other international organizations, it was not status neutral and did not have UNSC limitations, but was independence-supportive and as such, created solid ground and political basis for the state-building in Kosovo. ${ }^{14}$ This rather contextual and precise approach of ICO however, presented some sort of paradox and inconsistency on the ground, especially after the decision for the deployment of the EULEX mission based on the UN's six-point plan. The main fundamentals of the plan presented on the Secretary-General's report covered: Police, Customs, Justice, Transport and Infrastructure, Boundaries and Serbian Patrimony. ${ }^{15}$

This plan was not supported by the local authorities namely the president and the prime minister, but they were in favour of the EULEX deployment. The six-point plan also triggered protests with the motto "Against the six points, for sovereignty," ized by several non-governmental organizations, including the movement Vetevendosje!. The protestors blamed the government for not firmly refusing the six-point plan but silently

\footnotetext{
${ }^{14}$ I worked for ICO during 2008-2009 as a Religious and Cultural Policy Officer.

15 "Report of the Secretary-General on the United Nations Interim Administration Mission in Kosovo: S/2008/692". UN Security Council. 24 November 2008. https://www.refworld.org/docid/492e79152.html, Accessed on 16 July 2019.

16 "Kosovo Protests UN Six-Point Plan for EULEX". Balkan Insight, 2 December 2008. http://www.balkaninsight. com/en/article/kosovo-protests-un-six-point-plan-for-eulex, Accessed 21 February 2019.
} 
implementing it thus allowing the return of Serbia. ${ }^{17}$ The deployment of EULEX followed the presidential statement at the UN Security Council based on Resolution 1244. ${ }^{18}$ While there were protests against the mandate of EULEX as an outcome of the above mentioned six-point plan, this affected the mandate of ICO as well. The latter was expected to cooperate and monitor EULEX's work in accordance with the laws of the Kosovo Constitution based on Ahtisaari's plan, therefore locals expressed concerns about potential problems regarding the oversight of the EULEX in terms of legal framework. ICO on the other hand was firm about its mandate, claiming that regardless of the six-point plan EULEX operation is based on UNSC 1244 while ICO will continue to supervise the implementation of the Ahtisaari Plan and cooperate with the Government of Kosovo. According to them, the six-point agreement of New York-Belgrade-Brussels for the reconfiguration of the international civilian presence in Kosovo was an interim agreement that will serve to pave the way for the deployment of the EULEX mission. ${ }^{19}$

From security point of view, the protection of Serb religious and cultural heritage, as set in Annex V of the Ahtisaari's Comprehensive Proposal, had a special attention. ${ }^{20}$ The protection of the Serbian religious and cultural sites shall constitute a special operational task of the KPS. The ESDP Rule of Law mission, in consultation with the International Military Presence (IMP), shall monitor, mentor and advise the KPS in the implementation of this task. ${ }^{21}$ In fact, Serbs even before the independence had set out their conditions for the Serbian Patrimony which were then embodied in the status proposal of Ahtisaari, for which Kosovo not only agreed but also made commitments to comply fully. The protection of the religious sites was a core responsibility of KFOR, EULEX and Kosovo Police, which was gradually handed over to the local institutions as the security situation improved. The decision taken by North Atlantic Council in March 2010, for the protection of one of the most important monuments for the Serb heritage - Gazimestan - to be handed over from KFOR to the Kosovo Police presented an advancement of the responsibility as well as reflected the confidence that NATO and KFOR contributing partner nations have in the capability of the Kosovo Police to perform this task.

In regards to the legislative agenda that contributed to the security development, the ICO Planning team provided a vast technical assistance. Based on this assistance the Assembly of Kosovo adopted 19 laws that entered into force on 15 June 2008 in the Constitution of Kosovo. ${ }^{22}$ This preliminary package contained important security laws such as: Kosovo Police, Kosovo Police Inspectorate, Ministry for the Kosovo Security Force, Kosovo Security Force - that laid the foundation for the security architecture of the state. However, from security point of view, the situation on the ground was very complex both internationally and domestically. UNMIK was regarded as a mission that had fulfilled its mandate once the

\footnotetext{
17 Vetevendosje! is currently one of the biggest opposition parties in Kosovo that has been constantly vocal against international and local deals that would in one way or another affect territorial integrity and sovereignty of Kosovo.

18 "Declaration by the Presidency on behalf of the European Union on the deployment of EULEX". Council of the European Union. http://europa.eu/rapid/press-release PESC-08-147 en.htm, Accessed on 21 February 2019.

19 Peci, E. "EULEX-i neutral (s')kërcënon mandatin e ICO-së". Radio Free Europe. https://www.evropaelire. org/a/1354530.html, Accessed on 21 February 2019.

20 "Comprehensive Proposal for Status". 37-38.

21 "Comprehensive Proposal for Status". 37-38.

22 State Building and Exit: The International Civilian Office and Kosovo's Supervised Independence $2008-2012$. Pristina: ICO, 2012.8.
} 
country was declared independent while "the EU was on the verge of launching its most ambitious security and defence mission, EULEX, an arrangement that would not see Belgrade's cooperation anytime soon". ${ }^{23}$

The security situation in North Mitrovica deteriorated with violence when on 17 March, 2008 members of the Serb community protested against the declaration of independence of Kosovo. Subsequently, they took over an empty UN courthouse building. Even though this violent confrontation lasted for several hours, UN Police and KFOR soldiers overmastered the courthouse building. Following this event, UN and Kosovo Police as well as KFOR withdrew from the north. Their withdrawal created a security vacuum in an area where criminal activity was widespread. This period was a test for the dynamics amid UNMIK, ICO, KFOR, Kosovo Police and other international actors who were monitoring a tense and uncertain situation. The international community was not in unison nor spoke in one voice as to finding the right approach to the north to impede any further deterioration of the situation. ${ }^{24}$ From my personal experience working with ICO, I could notice that even within ICO there were divergences particularly over North Mitrovica, which led to the eventual withdrawal of ICO from there.

Another remarkable contribution of ICO in terms of security development, was the successful conclusion of the border demarcation between Kosovo and Macedonia. ICO played an essential role that had an impact amongst others on border security and stability. After a couple of years of difficulty to demarcate the border of Kosovo with Montenegro due to the refusal by the opposition, the demarcation ICO undertook, is recalled as a very successful exercise.

Lastly, ICO is appraised for two distinct stages, first for its focus on stabilization through establishment and consolidation of the main state institutions and the second the enhancement of local ownership through transferring of responsibilities to the Kosovo authorities and the EU.

As Peter Feith puts it: "Our relationship to the political elite was based on equal partnership, rather than on intrusive international scrutiny that Kosovo had experienced during the preceding decade," 25 and having worked in this organization and for almost a decade in other international organizations in Kosovo, I could not agree more. However, while the role of ICO must be appraised for the partnership approach and assistance in state building process and for what was elaborated above, its mandate inopportunely remained unfulfilled from the security point of view given that the Ahtisaari Plan endured unenforced in the north of the country, a challenge that ICO foresaw and the consequences of which are distressing the sovereignty and security situation of the country to this day.

\section{ORGANIZATION FOR SECURITY AND COOPERATION IN EUROPE MISSION IN KOSOVO}

The OSCE Mission in Kosovo (OMiK) was established in 1999 and it is the second largest field operation. It is the only international civilian organisation that is present in the entire territory of Kosovo and that monitors political and institutional developments as well as the

\footnotetext{
23 State Building and Exit... 13.

24 State Building and Exit... 14.

25 Feith, P. “Overseeing Kosovo's Conditional Independence” European Council on Foreign Relations, Commentary". https://www.ecfr.eu/article/commentary_overseeing_kosovos_conditional_independence, Accessed on 21 February 2019.
} 
developments in the field of security. In terms of institution building, the Mission has been engaged in establishing many key institutions, like the Assembly of Kosovo, the Ombudsperson Institution, the Central Election Commission, the Office of the Language Commissioner, municipal community protection bodies, etc. ${ }^{26}$ The mandate of the mission is determined by UNSC Resolution 1244 based on Decision 305 of July, 1999 of the Permanent Council of the OSCE.

In terms of security, OMiK supports ministries and law enforcement agencies to review strategies and action plans regarding the fight against different security threats such as organized crime, violent extremism, terrorism, etc., as well as the strategies on intelligence-led policing, community policing and safety. It works on expanding police-public partnerships through fostering dialogue between the communities and police. It has established a number of community safety forums through which the security issues are addressed while working to establish new ones in the northern part of Kosovo. OMiK works towards increasing the representation of communities and gender in police and other managerial positions. Police is also monitored for the compliance with human rights. ${ }^{27}$ Hence, OMiK still has an important role in the security sector development and advancement.

The functional mandate of OMiK's thematic departments derives from the OSCE's General Council Decision no. 305, ${ }^{28}$ approved on 01 July 1999, which explicitly refers to UNSCR 1244, thus the mandate of the OSCE is defined directly through this Resolution and it constitutes one of UNMIK's main pillars. This decision mandates OMiK with a leading role in institution building, democratisation and human rights. Through this reference, $\mathrm{OMiK}$ extends its mandate from one year to the other while the relations with Kosovo are quite paradoxical due to the obsolete authorisation of its mandate. This presents one of the main obstacles for the coordination, planning and identification of the needs of the Republic of Kosovo vis-a-vis OMiK's programs.

This does not in any way mean that many of these programs and institutions, which have been established by OMiK, are not suitable; on the contrary, many of them have laid grounds for respect for human rights such as the Ombudsperson, the rule of law efficiency, police academy then affirmation of institutions from modern media standards to accommodating minority rights in the Republic of Kosovo and as such have contributed to the security sector development. However, OMiK's referral to 1999's decisions and the completely new situation created in the Republic of Kosovo (especially after the declaration of independence, and the great advancement of the fundamental definition of the subjectivity and sovereignty of the state of Kosovo in the international sphere) are not in line with the priorities of the institutions of the Republic of Kosovo. Consequently, this approach clearly shows there is a lack of coordination with OMiK's programmatic work in Kosovo that in an ideal scenario should take into consideration the needs of the Kosovo institutions and involve them in the planning process and not only in the implementation phases. ${ }^{29}$

\footnotetext{
26 "Mission in Kosovo". Factsheet. Organization for Security and Co-operation in Europe (OSCE). Pristina, 2017. https://www.osce.org/mission-in-kosovo/143996?download=true

27 "Mission in Kosovo".

28 "Decision No. 305. PC.DEC/305." Permanent Council of Organization for Security and Co-operation in Europe (OSCE). PC Journal 237. Agenda item 2., 1 July 1999. Parag. 6. https://www.osce.org/pc/28795?download=true

${ }^{29}$ Coordination of Priorities and a Coordinated Technical-Content Modality with OMiK and Proactive Approach to OSCE Member States. Internal Draft Concept Document of the Ministry of Foreign Affairs. Department for NATO and Security Policies: Pristina, 2018.
} 
In the political sphere, in the framework of relations with the Permanent Council and the OSCE Secretariat, ${ }^{30}$ Kosovo is regrettably formally addressed in full reference to Resolution 1244 and the Decision 305 of 1999 of the OSCE. As indicated above, not only with regards to the relations with $\mathrm{OMiK}$ but also when ministerial meetings of the member states are concerned, starting from the OSCE Permanent Council to the lowest level fora, the entire correspondence related to Kosovo including official documents does not mention Kosovo institutions while uses the asterisk that refers to UNSCR 1244. There are cases when discussions in meetings exceed OMiK's respective content, especially through non-recognizing states, primarily by Serbia and Russia, which also serve to create an opinion about the image and situation in Kosovo by voicing issues of daily politics and processes outside the contextual mandate of OMiK. Thus, Kosovo is not allowed to participate during the OMiK Chief of Staff semester reporting to the OSCE's Permanent Council which is not the case for example with the UNSC when reporting about Kosovo, where the Kosovo Government is present and reports.

Therefore, Kosovo does not participate in any formal OSCE activities even though $\mathrm{OMiK}$ is the second largest mission - out of the 16 existing OSCE field missions. Even though the scope of the mandate encompasses the security sector and particular security institutions from various perspectives, OMiK has the tendency to run its own programs without consulting Kosovo institutions for their needs. This is best illustrated by the OSCE Programme Outline 2019 SEC.GSL/65/18 for the OSCE missions, ${ }^{31}$ where in the part for Kosovo in the first paragraph it is stated that the new strategic framework will take into consideration the specific role and expertise of the mission that has been realized over years and will aim to further clarify the mission's focus in the fields where the OSCE possesses added values. The role and the expertise of the mission should go hand in hand with the development needs of the Kosovo institutions which in fact should present the core reasons of OMiK presence in Kosovo. Furthermore, the respective document indicates that the OSCE will continue to implement its activities in coordination with the international community without mentioning or referring to the institutions of Kosovo. Hence to prove this point or rather the concerns raised by the Kosovo side, even this very important document about the work of the OSCE does not refer directly to the consultations with the Kosovo institutions or to a formal orientation along priorities of the Government of Kosovo which are covered by OMiK. ${ }^{32}$ While acclaims for some segments of security sector development are undeniable, still they tend not to go in a two way direction.

To this end, membership in the OSCE is one of the long-term aims of Kosovo. Yet, Kosovo should persuade member states for new forms of cooperation that goes beyond the obsolete documents of 1999 and at the same time lobby and "convince" them about the benefits of its membership, from the security point of view in particular. Kosovo's membership would have resolved the problems of interaction and as well definition of programs deriving from the necessities of the institutions would have been more adequate. This certainly will depend on the dynamics of the geopolitics circumstances but one thing is for sure, it would have contributed to the overall security in the region and advancement of the security institutions of Kosovo.

\footnotetext{
${ }^{30}$ The Secretariat consists of 57 member states, where over half of them have recognised the independence of the Republic of Kosovo.

31 "OSCE-2019 Programme Outline". SEC.GAL/65/18. Restricted Document. Organization for Security and Co-operation in Europe. 2018. 10.

32 "OSCE-2019 Programme Outline". 10.
} 


\section{THE ROLE OF NATO IN KOSOVO - SECURITY AND BEYOND}

Since June 1999, NATO, namely Kosovo Force (KFOR) has been leading a peace-support operation in Kosovo as the main supporter of wider international efforts for peace and stability. KFOR was established after the air campaign against Milosevic's regime. This air campaign was launched by the Alliance in March 1999 to stop the humanitarian catastrophe that was then unfolding. The mandate of KFOR derives from United Nations Security Council Resolution (UNSCR) 1244 of June 1999 and the Military-Technical Agreement between NATO and the Federal Republic of Yugoslavia and Serbia. KFOR operates under Chapter VII of the UN Charter and, as such, conducts a peace enforcement operation. ${ }^{33}$

KFOR's mandate is to deter renewed hostility and threats against Kosovo by Yugoslav and Serb forces; establish a secure environment and ensure public safety and order; demilitarize the Kosovo Liberation Army; support the international humanitarian effort; and coordinate with, and support, the international civil presence. KFOR continues to help "maintain a safe and secure environment and freedom of movement for all people and communities in Kosovo." 34

Martin A. Smith and Paul Latawski claim that the NATO air operations against the government of Milosevic have been among the most controversial aspects of the Alliance's involvement in South East Europe since the end of the Cold War. Many critics and scholars qualified the military intervention in different ways, such as 'humanitarian war', 'virtual war', intervention and 'humanitarian intervention'. Nonetheless, the debate over the use of force was mainly concerned with the legality and legitimacy as well as the ethic basis and its impact on the principle of non-interference in the internal affairs of states. They further argue that these conceptual debates are important not only within the context of European security but for the international system as a whole. ${ }^{35}$

Certainly, the rationale of NATO and its member states was clear, first, all diplomatic efforts and actions were exhausted and second, there were imperative humanitarian considerations. Military power was employed to support the political aim, as the Serbian actions were in breach of the core values and norms embraced by the "Atlantic Community" namely NATO. ${ }^{36}$

With the passage of time, as the security situation has improved, NATO has been gradually adjusting KFOR's posture towards a smaller and more flexible force with fewer static tasks. The North Atlantic Council decides about all adjustments to the KFOR posture conditional to the evolvement of the security situation on the ground. KFOR cooperates and coordinates with the United Nations (UN), the European Union (EU) and other international actors to support the development of a stable, peaceful, democratic and multi-ethnic Kosovo. ${ }^{37}$

\footnotetext{
33 “NATO’s role in Kosovo”. North Atlantic Treaty Organization (NATO). 29 November 2018. https://www.nato. int/cps/en/natohq/topics_48818.htm, Accessed on 21 February 2019.

34 NATO's role in Kosovo".

${ }^{35}$ Latawski, P. and Smith, M. A. The Kosovo crisis and the evolution of post-Cold War European Security. Manchester: Manchester University Press, 2003. 165.

${ }^{36}$ Latawski and Smith. The Kosovo crisis... 165.

${ }^{37}$ Latawski and Smith. The Kosovo crisis... 165.
} 


\subsection{MILLION PEOPLE EXPELLED FROM THEIR HOMES}

- March and ongoing

- Over 2000 Albanians killed by Serb government

June- September

-250.000 Albanians expelled from their homes

- Cities and villages destroyed

1999

64,000

refugees

April

1999

33,000

refugees

Montenegro

May 1999:

580.000 homeless people

225.000 missing 5000 Kosovars executed

Albania

April

1999

226,000

refuge

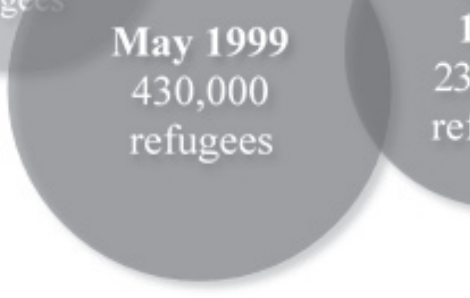

May 1999

430,000

refugees
- January

- UN revealed the massacre of over 40 civilians in the village of Recak

\section{- 24 March}

- Operation Allied Force: NATO strikes military targets in Serbia

Other countries: 61,000 Kosovars

Bosnia Herzegovina: 21,500 Kosovar refugees
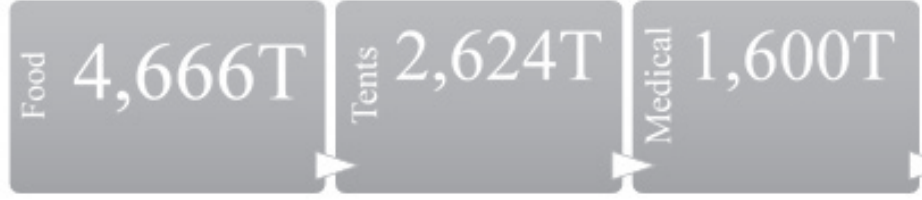

FYROM

NATO ASSISTANCE

Figure 1: NATO Kosovo Force United in Commitment 
The role of NATO in Kosovo was multifaceted while its operations evolved from the air war to humanitarian assistance to peacekeeping and peace building. ${ }^{38}$ As such, some of the units, such as civil affairs, significantly extended the mission in support of peace operations. Thus, civil affairs soldiers were out every day working with UNMIK to help set up local governments and restore electricity, water and telephone service. KFOR operates under the auspices of the UNSCR 1244 and through its military ensures peace and also supports UNMIK, the EULEX Civilian Crisis Management Operation as well as other international organisations. KFOR enjoyed and enjoys respect not only from Kosovo's institutions but also from its citizens because of its role in maintaining peace, security and stability in Kosovo. Another importance of the role of NATO in Kosovo other than its contribution to the peace and security through the mission of KFOR is its impact in the establishment, consolidation and functionalization of the KSF.

Currently, in Kosovo there are around 3,600 NATO troops run by KFOR, from 28 states (20 NATO members and 8 NATO partners), which continue to contribute to the maintenance of a safe and secure environment for all citizens.

\section{CONCLUSION}

The role of international organisations was indispensable in Kosovo both for providing security and creating its security architecture. The progression of the security policies in Kosovo since the end of the war has been handled and guided mainly by the international actors. Essentially, the security sector did not exist whereas the international military and civil presence was responsible for securing the borders of Kosovo as well as providing public order. This brings us to a rather oxymoronic situation if we consider the fact that most of the reports released by the organizations examined in this chapter are very critical to the public institutions of Kosovo while these same organisations were involved in the institution and capacity building of these very institutions. This situation ultimately suggests that part of the responsibility lies on the respective international organisations as well.

Rebecca J. Cruise and Suzette R. Grillot argue that the role of the international community is not over, claiming that the EU, NATO and the OSCE must continue to enhance the communication and collaboration at the elite-levels. According to them, these organizations must also continue and build up their pledge to funding and supporting local community through the project development with a special focus on those projects that intend to bridge ethnic divergences through an increased interaction. ${ }^{39}$ I agree that there is still a need for the international organisations' support given the fragility of the institutions, inner politicization and also external influences primarily of Serbia. Ethnic divergence is not as big as it is portrayed by the international organisations, most of the time it is an outcome of the political interference that comes from Serbia. In this light, Kosovo should be proactive and more inclusive and work very closely with the local Serbs. The constitution of Kosovo generously grants them all rights and other affirmative actions in line with international standards and as such they should take their fates in their own hands and make decisions without interference from Belgrade. Once an extensive local ownership of all communities living in Kosovo is

\footnotetext{
${ }^{38}$ Wentz, L. K. "Introduction". In Wentz, L. K. (ed.), Lessons from Kosovo: The KFOR Experience. Washington, D.C.: CCRP, 2002. 3-7.

${ }^{39}$ Cruise, R. J. and Grillot, S. R. "Regional Security Community in the Western Balkans: A Cross-Comparative Analysis". Journal of Regional Security 8/1. 2013.21.
} 
reached, the level of accountability will be increased along with the reduction of eventual divergences. Sonja Stojanovic Gajic rightly finds that in the initial two phases of SSR the coordination of the international community was much better and this is attributed to the executive role of the UN mission as a main pillar that managed to integrate major intergovernmental actors such as the OSCE, the EU and KFOR and more openly defined the distributions of tasks between them. However, in regard to capacity building that would lead to an increased local ownership, there was no coherence in terms of transferring articulate models to local authorities. Much of the work was undertaken by the contingents of the member states or senior representatives of the international organizations, which resulted in the application of their respective national models. ${ }^{40}$ She further claims that the partial engagement of local actors in security governance during the stabilization and demobilization phase precluded the development of local ownership. ${ }^{41}$ However, after the inclusion of Kosovo institutions in the security sector, the commencement of the security sector review process developed accordingly along with the overall political developments. Throughout this process the most significant development was the Internal Security Sector Review (ISSR) that gave way to the creation of the new security architecture in Kosovo and most importantly the establishment of two important ministries, the Ministry of Internal Affairs, and the Ministry of Justice. Finally, in the new security architecture in Kosovo the new institutions were created: KSF, KSC, KIA including reforms in police and emergency services. What is most important, the SSSR referred to the gradual transformation of the KSF to the Kosovo Armed Forces (KAF), whose mission will be the protection of the territorial sovereignty and integrity of Kosovo whereas the MKSF will be turned into the Ministry of Defence (MoD), which will exercise civil and democratic control of the KAF. All these developments happened with support and mentoring and international supervision which leads to the conclusion that the role of international organizations in the creation and structuring of the security mechanisms has been indispensable. However, the question to ask is: what is the exit strategy for the international organisations in Kosovo? What benchmarks determine their continuation of operation in Kosovo or redefinition of their mandates, which as examined in this chapter, should be in line with the needs of the Kosovo institutions. The response though politically very complex, is very simple: peace, stability, sustainable development can only be ensured once Kosovo becomes member of the Euro-Atlantic structures and this is what actually sets the basis for the withdrawal of the international organizations from Kosovo.

\section{BIBLIOGRAPHY}

Annan, K. A. "Letter dated 7 October 2005 from the Secretary-General addressed to the President of the Security Council". 7 October 2005. https://www.securitycouncilreport.org/atf/cf/\%7B65BFCF9B-6D27-4E9C-8CD3-CF6E4FF96FF9\%7D/Kos\%20S2005\%20635.pdf, Accessed on 12 July 2019.

"Chronology of Security Sector Reform in Kosovo". Kosovar Center for Security Studies (KCSS). Pristina, 2009. http://www.qkss.org/repository/docs/Chronology of Security Sector Reform in_Kosovo 609982.pdf

\footnotetext{
${ }^{40}$ Gajić, S. S. "Capacity Building for Security Sector Reform in Kosovo". EU-CIVCAP Working Paper 2. 2017. 2. https://eucivcap.files.wordpress.com/2017/09/eucivcap-workingpaper-02-17-stojanovic gajic.pdf

${ }^{41}$ Gajić. "Capacity Building for Security Sector Reform in Kosovo". 2.
} 
"Comprehensive Proposal for the Kosovo Status Settlement". United Nations Office of the Special Envoy for Kosovo (UNOSEK). 2 February 2007. http://www.kuvendikosoves.org/common/docs/ Comprehensive\%20Proposal\%20.pdf

Coordination of Priorities and a Coordinated Technical-Content Modality with OMiK and Proactive Approach to OSCE Member States. Internal Draft Concept Document of the Ministry of Foreign Affairs. Department for NATO and Security Policies: Pristina, 2018.

Cruise, R. J. and Grillot, S. R. "Regional Security Community in the Western Balkans: A Cross-Comparative Analysis”. Journal of Regional Security 8/1. 2013. 7-23. DOI: 10.11643/issn.2217995x131spc25

"Decision No. 305. PC.DEC/305." Permanent Council of Organization for Security and Co-operation in Europe (OSCE). PC Journal 237. Agenda item 2., 1 July 1999. https://www.osce.org/ pc/28795?download=true

"Declaration by the Presidency on behalf of the European Union on the deployment of EULEX". Council of the European Union. http://europa.eu/rapid/press-release_PESC-08-147 en.htm, Accessed on 21 February 2019.

Feith, P. “Overseeing Kosovo's Conditional Independence” European Council on Foreign Relations, Commentary”. https://www.ecfr.eu/article/commentary_overseeing_kosovos_conditional_independence, Accessed on 21 February 2019.

Gajić, S. S. "Capacity Building for Security Sector Reform in Kosovo". EU-CIVCAP Working Paper 2. 2017. https://eucivcap.files.wordpress.com/2017/09/eucivcap-workingpaper-02-17-stojanovic_gajic.pdf

International Commission on the Balkans. The Balkans in Europe's Future. Sofia: Secretariat Centre for Liberal Strategies, 2005.

"International Support for Kosovo". U.S. State Department of State. https://2009-2017.state.gov/p/eur/ ci/kv/c27789.htm, Accessed on 12 July 2019.

Knoll, B. "From Benchmarking to Final Status? Kosovo and The Problem of an International Administration's Open-Ended Mandate”. European Journal of International Law 16/4. 2005. 4-12.

DOI: $10.1093 /$ ejil/chil40

“Kosovo Protests UN Six-Point Plan for EULEX”. Balkan Insight, 2 December 2008.

http://www.balkaninsight.com/en/article/kosovo-protests-un-six-point-plan-for-eulex, Accessed on 21 February 2019.

Latawski, P. and Smith, M. A. The Kosovo crisis and the evolution of post-Cold War European Security. Manchester: Manchester University Press, 2003.

"Mission in Kosovo". Factsheet. Organization for Security and Co-operation in Europe (OSCE). Pristina, 2017. https://www.osce.org/mission-in-kosovo/143996?download=true

"NATO’s role in Kosovo". North Atlantic Treaty Organization (NATO). 29 November 2018. https://www.nato.int/cps/en/natohq/topics_48818.htm, Accessed on 21 February 2019.

“OSCE-2019 Programme Outline". SEC.GAL/65/18. Restricted Document. Organization for Security and Co-operation in Europe. 2018.

Peci, E. “EULEX-i neutral (s')kërcënon mandatin e ICO-së”. Radio Free Europe. https://www.evropaelire.org/a/1354530.html, Accessed on 21 February 2019.

"Secretary-General Appoints Former President Martti Ahtisaari of Finland as Special Envoy for Future Process for Kosovo". United Nations. https://www.un.org/press/en/2005/sga955.doc.htm, Accessed on 16 February 2019.

"Security Council Resolution 1244 (1999) on the situation relating Kosovo". United Nations Peacemaker. https://peacemaker.un.org/kosovo-resolution1244, Accessed on 16 February 2019. 
State Building and Exit: The International Civilian Office and Kosovo's Supervised Independence 2008 - 2012. Pristina: ICO, 2012.

"Report of the Secretary-General on the United Nations Interim Administration Mission in Kosovo: S/2008/692". UN Security Council. 24 November 2008. https://www.refworld.org/docid/492e79152.html, Accessed on 16 July 2019.

"UNMIK/REG/2001/9. On a Constitution Framework for Provisional Self-government in Kosovo". 15 May 2001. http://www.unmikonline.org/regulations/2001/reg09-01.htm, Accessed on 16 July 2019.

Wentz, L. K. "Introduction". In Wentz, L. K. (ed.), Lessons from Kosovo: The KFOR Experience. Washington, D.C.: CCRP, 2002. 3-15. 